\title{
USE OF LIGNOSILICON TO IMPROVE THE HARVEST AND QUALITY PARAMETERS OF POTATO
}

\author{
Galina Lebedeva $^{1}$, Valentin Solodovnik ${ }^{1}$, Galina Telysheva ${ }^{1}$, \\ Jānis Vigovskis ${ }^{2}$, Agrita Švarta ${ }^{2}$ \\ 1- Latvian State Institute of Wood Chemistry, 27 Dzerbenes str., Riga, LV 1006, Latvia \\ Ph.: + (371)67555916, fax: + (371)67550635, e-mail: lclgl@edi.lv \\ 2- LUA Agency "Research Institute of Agriculture" \\ 7 Zemkopibas inst. str., Skriveri, Skriveri region, LV 5125, Latvia \\ Ph.: + (371)5197529, Fax: + (371)5197512, e-mail: vigovskis@apollo.lv
}

\begin{abstract}
Lignosilicon (LSi), a plant growth activator, was synthesized at the Latvian State Institute of Wood Chemistry (LS IWC) on the basis of the wood lignocellulosic complex. It is shown that LSi, used for treatment of potato tubers before sowing at low application rates of 20-40 kg/ha, has a favourable action on the yield and quality of the tubers. In comparison with the control, the additional yield achieved on the background of LSi (20-40 kg/ha) was 18-20\%. The best biochemical composition was for the tubers wetted with water and LSi-treated before the sowing, i.e., the content of dry matter and starch increased by $16 \%$ and 18\%, respectively, but the content of nitrates in the tubers decreased 1.6 times. LSi can be recommended for potato cultivation under conditions of conventional and organic agriculture.
\end{abstract}

Keywords: lignosilicon, potato tuber yield, tuber quality.

\section{Introduction}

The results of the investigation of Lignosilicon (LSi) - a plant growth and development activator, synthesized on the basis of the wood lignocellulosic complex, showed the efficiency of its use at low application rates (20-120 $\left.\mathrm{kg} \mathrm{ha}^{-1}\right)$ in conventional and organic agriculture for cereals and grain legumes such as oat [1], rye [2], buckwheat [3], and red clover [4, 5]. On the background of LSi, the activation of the development of the plant root system was observed at the early stages of vegetation (30-50 days after sowing), which later favoured higher crop, as well as its quality of crops and soil agrochemical parameters. In comparison with cereals, potato has less demand to siliceous consuming capacity.

Silicon uptake by cereals is around $120 \mathrm{~kg}$ of $\mathrm{SiO}_{2}$ from 1 ha per year, whereas that by potato is $8 \mathrm{~kg}$ [6, p.122]. Setting of loss of a plant available silicon (at least partial) through soil treatment with siliceous compounds could have a favourable action on the soil, the crop and its quality. There are no scientific data on the use of silicon-containing growth activators in potato cultivation. Potato, besides wheat, rice and maize, belongs to the world's major food, fodder and industrial crops. The nutritional value of potato is determined by the presence of digestible carbohydrates, first of all, starch, as well as the qualitative and quantitative composition of minerals. In terms of the total content of minerals, potato exceeds various vegetables and fruits. Potato contains a whole range of microelements rarely met in other products. At a mean ash content of about $1 \%$ in tubers, more than a half of all ash elements fall on potassium. The greater part of potato minerals is represented by alkaline salts such as potassium, sodium, magnesium, calcium and iron, which are essential elements in human nutrition and important for maintaining the alkalinity of blood.

For the Baltic Sea region, potato is a very valuable product. It serves as one of the main sources of ascorbic acid (vitamin $\mathrm{C}$ ). The content of ascorbic acid in tubers regionalised in Latvia varies from 10 to $26 \mathrm{mg} \%$. While the content of vitamin $\mathrm{C}$ decreases in storage, the content of other vitamins $\left(\mathrm{B}_{1}, \mathrm{~B}_{2}, \mathrm{~B}_{3}, \mathrm{~B}_{6}, \mathrm{PP}\right)$ and minerals remains practically the same. In modern farming technologies, potato yield can reach 50-70 t ha ${ }^{-1}$ [7]. However, only 15-20\% 
of this potential is realized. In agricultural practice the average yield of potato in Western Europe and in Latvia is 40-50 $\mathrm{tha}^{-1}$ [7] and $17 \mathrm{t} \mathrm{ha}^{-1}$ [8], respectively. An important reserve for increasing potato yield as well as potato growth ecologization is the use of growth activators of natural origin, including products synthesized on the basis of natural organic raw materials.

From 2007, LSi (application rates 10-30 $\mathrm{kg} \mathrm{ha}^{-\mathbf{1}}$ ) has been tested in cultivation of the potato varieties "Adora", "Latona", "Red scarlet", "Asterix" in private Latvian farms. The farmers noticed an earlier ripening of tubers (by 5-7 days), the improvement of tubers' taste and quality parameters, namely, decreased level of nitrates, and increased content of dry matter and starch. The tubers grown on the background of LSi differed from the control by better winter storing. In spring, $99 \%$ of tubers could be used as seed tubers. These experiments were used as the basis for setting microfield experiments in 2009-2010.

The aim of the work was to evaluate the effect of low rates of LSi application $\left(10 \mathrm{~kg} \mathrm{ha}^{-1}, 20\right.$ $\mathrm{kg} \mathrm{ha}^{-1}$ and $40 \mathrm{~kg} \mathrm{ha}^{-1}$ ) on potato plant tuberization and productivity, improvement of the quality and biochemical composition of tubers.

\section{Materials and methods}

In the growing season of 2009-2010 field trials were carried out at the Research Institute of Agriculture of the Latvian University of Agriculture using the medium early table potato variety 'Lenora'.

The variety 'Lenora' was bred by the Priekuli Plant Breeding Institute and grown in Latvia from 2003. 'Lenora' is a highly productive variety, suitable for cultivation in both conventional and organic agriculture, and resistant to viral diseases, nematodes, and cancer. The variety is characterised by round tubers with bright yellow skin and yellow flesh. The productivity of 'Lenora' can reach 40-45 $\mathrm{tha}^{-1}$.

LSi $(5 \% \mathrm{Si})$ is a silicon-containing product synthesised by the Latvian State Institute of Wood Chemistry (IWC) from the wood lignocellulosic complex.

Characteristics of the soil used: turf podsolic soil $\mathrm{pH}_{\mathrm{KCl}}$ 6.1-6.2, organic matter content $2.5 \%, \mathrm{P}_{2} \mathrm{O}_{5} 90-152 \mathrm{mg} \mathrm{kg}^{-1}, \mathrm{~K}_{2} \mathrm{O} 121-150 \mathrm{mg} \mathrm{kg}^{-1}$.

Planned plant density 47619 plants per $\mathrm{ha}^{-1}$, with the area of plant nutrition $0.21 \mathrm{~m}^{2}$ $(0.30 \mathrm{~m} \times 0.70 \mathrm{~m})$, according to the optimal potato growing conditions.

In 2009, the complex fertilizer NPK 12:6:15 - $700 \mathrm{~kg} \mathrm{ha}^{-1}$ was used. There were 3 variants with different application rates of LSi in 3 replications: 1. control; 2. LSi $-10 \mathrm{~kg} \mathrm{ha}^{-1} ; 3$. $\mathrm{LSi}-20 \mathrm{~kg} \mathrm{ha}^{-1}$.

Potatoes were planted by hand with the application of mineral fertilizers. The potatoes planted on 15 May, harvested on 17 September.

For limiting of pigweed (Chenopodium album L.) and buckwheat (Fagopyrum esculentum), the herbicide Titus (active ingredients Rimsulfuron $250 \mathrm{~g} \mathrm{~kg}^{-1}$ ) was applied (19 June).

Late blight (Phythophtora infestans (Mont.) de Bary) control started on 29 June. Sprayings with the system and contact fungicide Ridomil Gold $2.5 \mathrm{~kg} \mathrm{ha}^{-1}$ (Mankoceb 64\%, Metalaksil M $4 \%$ ) took place with a 14-day interval. The next spraying was carried out on 14 July with a mixture of the fungicide Ridomil Gold $2.5 \mathrm{~kg} \mathrm{ha}^{-1}$ and the insecticide Fastak (Alfa-cipermetrin $50 \mathrm{~g} \mathrm{l}^{-1}$ ). The third spraying took place on 30 July with the contact fungicide Ditan $2 \mathrm{~kg} \mathrm{ha}^{-1}$ (Mankoceb $750 \mathrm{~g} \mathrm{~kg}^{-1}$ ).

In 2010, the complex fertilizer NPK 12:11:18 - $500 \mathrm{~kg} \mathrm{ha}^{-1}$ was used. There were 3 variants with different application methods of LSi in 3 replications: 1 . control; 2 . LSi $-40 \mathrm{~kg} \mathrm{ha}^{-1}$ - dry tubers mixed with LSi in a container; 3 . LSi $40 \mathrm{~kg} \mathrm{ha}^{-1}$ - tubers were moistened with water in a container, then mixed with LSi ("wet" treatment of tubers).

Potatoes were planted by hand with the application of mineral fertilizers. The potatoes planted on 17 May harvested on 14 September. 
Late blight control started on 20 July (first spraying. The fungicide Infinito $150 \mathrm{ml} \mathrm{ha}^{-1}$ (Propamokarb $523.8 \mathrm{~g} \mathrm{l}^{-1}$, Propamokarb hydrochloride $625 \mathrm{~g} \mathrm{l}^{-1}$, Fluopicolide $625 \mathrm{~g} \mathrm{l}^{-1}$ ) was used. Subsequent sprayings (3 times) took place with 10-14 day intervals.

Harrowing was performed once before potato shoot emergence, and then three times after.

In each trial, 10 plants were analysed; production of commercial standard tubers (with the diameter $35 \mathrm{~mm}-75 \mathrm{~mm}$ ) from one plant ( $\mathrm{kg}$ and \% from the total yield) was estimated.

Potato samples were analysed using the corresponding ISO. The dry matter content in tubers was determined by weighing (ISO 6498:1998), ash elements - by LVS EN ISO 16472:2006, content of starch - by ISO 6493:2000, crude protein - by ISO 5983-2:2005, potassium - by LVS EN ISO 6869:2002, phosphorus - by ISO 6491:1998, the content of vitamin C - by LVS EN ISO 14130:2003. The nitrate content in tubers was determined by the ion-selective method [9].

\section{Results and discussion}

In 2009-2010, the favourable action of LSi in potato cultivation revealed itself not only in increased yield, but also in improved quality of tubers at LSi application rates of more than 20 $\mathrm{kg} \mathrm{ha}^{-1}$ (Tables 1, 2).

On the whole, the vegetation period of $\mathbf{2 0 0 9}$ was favourable for potato cultivation. In June, the mean air temperature was close to the mean long-term standard of $+14.0^{\circ} \mathrm{C}$ or lower by 0.7 degrees; in its turn, the precipitation rate was $120 \%$ from the standard. In July, the air became warm, the mean air temperature reached $+17.4^{\circ} \mathrm{C}(0.6$ degrees higher than the standard), but the precipitation rate reached $120 \%$ from the standard. The high air temperature corresponded to the standard, but the precipitation rate was only $90 \%$ from the standard [10]. The warm weather with regular rains favoured not only the growth and development of the plants, but also the spreading of plants' infecting with fungal diseases, which demanded the 3-times treatment of plants with fungicides. The favourable weather conditions ensured a good yield of tubers.

The analysis of the potato yield in 2009 has shown its $6 \%$ and $20 \%$ increase at LSi rates of $10 \mathrm{~kg} \mathrm{ha}^{-1}$ and $20 \mathrm{~kg} \mathrm{ha}^{-1}$, respectively (Table 1). In comparison with the control, the share of standard potatoes in the total yield in this case did not change (77-79\%). An analysis of the quality characteristics of the potatoes grown on the background of LSi $\left(20 \mathrm{~kg} \mathrm{ha}^{-1}\right)$ has shown that the starch content increased from $16.0 \%$ to $17.3 \%$, in comparison with the control. The content of vitamin $\mathrm{C}$ did not change, to be $18.0 \mathrm{mg} \%$ (Table 3 ).

Table 1.

Effect of LSi on the yield and crop structure of the potato variety 'Lenora' Skriveri, 2009

\begin{tabular}{|c|c|c|c|c|c|c|c|c|}
\hline \multirow{3}{*}{ Variants } & \multirow{3}{*}{$\begin{array}{l}\text { LSi, } \\
\text { kg ha-1 }^{-1}\end{array}$} & \multirow{3}{*}{$\begin{array}{l}\text { Total } \\
\text { yield, } \\
\text { t ha-1 }\end{array}$} & \multicolumn{6}{|c|}{ Yield structure } \\
\hline & & & \multicolumn{2}{|c|}{$\begin{array}{c}\text { Tubers, } \\
<35 \mathrm{~mm} \text { in diameter }\end{array}$} & \multicolumn{2}{|c|}{$\begin{array}{l}\text { Trade production of } \\
\text { tubers, } 35-75 \mathrm{~mm} \text { in } \\
\text { diameter }\end{array}$} & \multicolumn{2}{|c|}{$\begin{array}{c}\text { Tubers, } \\
>75 \mathrm{~mm} \text { in diameter }\end{array}$} \\
\hline & & & t ha $^{-1}$ & $\% *$ & t ha ${ }^{-1}$ & $\% *$ & t ha ${ }^{-1}$ & $\% *$ \\
\hline Control & 0 & 45.7 & 5.7 & 12.5 & 35.3 & 77.2 & 4.7 & 10.3 \\
\hline LSi & 10 & 48.3 & 8.7 & 18.0 & 36.5 & 75.6 & 3.1 & 6.4 \\
\hline $\mathrm{LSi}$ & 20 & 55.0 & 7.4 & 13.5 & 43.3 & 78.7 & 4.3 & 7.8 \\
\hline$L S D_{0.05}$ & & 1.23 & 1.25 & & 1.37 & & 0.54 & \\
\hline
\end{tabular}

* - from the total yield

In 2010, the LSi application rate was increased up to $40 \mathrm{~kg} \mathrm{ha}^{-1}$, and two methods of LSi application were tested, namely, addition to dry tubers and those to tubers wetted with water before the sowing (Table 2). 
Table 2.

Effect of different methods of LSi application for tubers treatment of the potato variety 'Lenora', before sowing, on the yield, Skriveri, 2010

\begin{tabular}{|c|c|c|c|c|c|c|}
\hline \multirow{3}{*}{ Variants } & \multirow{3}{*}{$\begin{array}{l}\text { LSi, } \\
\text { kg ha-1 }^{-1}\end{array}$} & \multirow{3}{*}{$\begin{array}{l}\text { Total yield, } \\
\text { t ha }^{-1}\end{array}$} & \multicolumn{4}{|c|}{ Yield structure } \\
\hline & & & \multicolumn{2}{|c|}{$\begin{array}{c}\text { Tubers, } \\
<35 \mathrm{~mm} \text { in diameter }\end{array}$} & \multicolumn{2}{|c|}{$\begin{array}{c}\text { Trade production of } \\
\text { tubers, } 35-75 \mathrm{~mm} \text { in diameter }\end{array}$} \\
\hline & & & $\mathrm{tha}^{-1}$ & $\% *$ & $\mathrm{t} \mathrm{ha}^{-1}$ & $\% *$ \\
\hline Control & 0 & 26.9 & 7.1 & 26 & 19.8 & 74 \\
\hline LSi -1 & 40 & 27.6 & 5.1 & 18 & 22.5 & 82 \\
\hline LSi -2 & 40 & 31.9 & 7.0 & 22 & 24.9 & 78 \\
\hline$L S D_{0.05}$ & & 1.54 & 0.62 & & 1.26 & \\
\hline
\end{tabular}

* - from the total yield

LSi - 1 - dry treatment of tubers with LSi;

LSi - 2 - "wet" treatment of tubers with LSi.

The use of LSi at the application rates $20 \mathrm{~kg} \mathrm{ha}^{-1}$ and $40 \mathrm{~kg} \mathrm{ha}^{-1}$ ensures the introduction of $1.5 \mathrm{~kg}$ and $3 \mathrm{~kg}$ of $\mathrm{SiO}_{2}$, respectively, into the soil.

The vegetation period of 2010 was warm, with a sufficient amount of precipitations [10]. However, long periods of drought were observed. In the $1^{\text {st }}$ and $2^{\text {nd }}$ decades of June, at the mean daily temperature of air conforming to the standard, there were practically no precipitations, but on 19 and 21 June, the total amount of precipitation was $48 \mathrm{~mm}$, which conforms to the monthly standard amount of precipitation. July was characterised by extremely hot weather: the average air temperature $\left(+21.5^{\circ} \mathrm{C}\right)$ exceeded by 4.8 degrees the long-term average standard. Rare heavy showers were observed: on 7 and 8 July, the amount of precipitation was $50 \mathrm{~mm}$, which corresponds to the monthly standard. August, the month of the ripening of potato tubers, was characterized by the mean daily air temperature $+18.8^{\circ} \mathrm{C}$, which exceeds the standard by 2.8 degrees. The amount of precipitation in August was $180 \%$ from the standard. Precipitation was very uneven, with prevailing heavy showers.

The weather conditions of 2010 were not favourable for tuber formation. A huge mass of foliage and a great quantity of small tubers $(<35 \mathrm{~mm})$ were formed, which did not manage to reach the sizes, corresponding to the trade production (Table 2). The majority of the tubers corresponded to the seed potato sizes, and there were no tubers with the diameter larger then $75 \mathrm{~mm}$.

At the dry LSi treatment of tubers (variant LSi-1, Table 2 ) before sowing, the additional yield in 2010 was only $2.6 \%$, although positive changes in crop structure were observed. The trade yield increased by $13.6 \%$ in comparison with the control, and yield of non-standard production decreased by $28.6 \%$.

At the "wet" LSi treatment of potato tubers (variant LSi-2, Table 2), the additional yield, in comparison with the control, was $18 \%$ at a $78 \%$ share of trade yield. In the control, it was $74 \%$. Hence, in the case of the application of LSi, the trade yield exceeded the control by $25 \%$, but the yield of dry protein by $20 \%$ (Table 3 ).

Table 3.

Effect of LSi on the biochemical indices of the tubers of the potato variety 'Lenora'

\begin{tabular}{|c|c|c|c|c|c|c|}
\hline Variants & $\begin{array}{c}\text { LSi, } \\
\mathrm{kg} \mathrm{ha}^{-1}\end{array}$ & $\begin{array}{c}\text { Dry matter, } \\
\%\end{array}$ & $\begin{array}{c}\text { Starch, } \\
\%\end{array}$ & $\begin{array}{c}\text { Crude } \\
\text { protein, \% }\end{array}$ & $\begin{array}{c}\text { Ascorbic acid, } \\
\text { mg \% }\end{array}$ & $\begin{array}{l}\mathrm{N}^{-\mathrm{NO}_{3},} \\
\mathrm{mg} \mathrm{kg}^{-1}\end{array}$ \\
\hline \multicolumn{7}{|c|}{2009} \\
\hline Control & 0 & 21.1 & 16.0 & 1.95 & 17.9 & $\ldots$ \\
\hline $\mathrm{LSi}$ & 20 & 21.3 & 17.3 & 2.00 & 18.1 & $\ldots$ \\
\hline \multicolumn{7}{|c|}{2010} \\
\hline Control & 0 & 23.3 & 16.8 & 2.00 & 18.0 & 71 \\
\hline $\mathrm{LSi}-2$ & 40 & 27.1 & 19.8 & 2.12 & 18.3 & 43 \\
\hline$L S D_{0.05}$ & & 0.5 & 0.7 & 0.05 & 0.8 & 16 \\
\hline
\end{tabular}


The obtained results testify that the "wet" treatment of potato tubers with LSi promotes the enhancement of the total yield and marketable yield. At such a method of treatment, better retaining of LSi on the tubers is ensured, which is very important at low application rates of LSi.

In 2010 the potato grown on the background of LSi had the better quality indices then the potato of control variants: the content of nitrates decreased by 1.6 times, but the contents of dry matter and starch increased by $16 \%$ and $18 \%$, respectively. In the control, the content of dry matter was $23.3 \%$, including the contents of starch, protein and mineral salts $16.8 \%$, $2.0 \%$, and $1 \%$, respectively. On the background of LSi, the content of dry matter was $27.1 \%$, including the contents of starch, protein and mineral salts $19.8 \%, 2.1 \%$ and $1.1 \%$, respectively. The content of ascorbic acid remained the same, to be $18.0 \mathrm{mg} \%$. The potassium content tended to increase, but the phosphorus content tended to decrease.

\section{Conclusions}

- Lignosilicon, at the application rates more than $20 \mathrm{~kg} \mathrm{ha}^{-1}$, has a favourable action on the yield and quality of potato tubers.

- The additional yield of potato on the background of the $20-40 \mathrm{~kg} \mathrm{ha}^{-1}$ of LSi, in comparison with the control, is $18-20 \%$.

- The best biochemical composition were detected for potato tubers grown on the background of $40 \mathrm{~kg} \mathrm{ha}^{-1}$. In this case, the trade yield exceeds the control by $25 \%$, and the yield of dry protein by $20 \%$, the content of dry matter and starch increases by $16 \%$ and $18 \%$, respectively, and the content of nitrates decreases 1.6 times.

- The technique of "wet" treatment of potato tubers before sowing can be recommended for more efficient use of low application rates of Lignosilicon.

\section{References}

1. Serge, I., Biteniece, G., Telysheva, G., Lebedeva, G., Lielpetere, A. Application of lignosilicon and azotobacterine for biological agriculture. - In: Proc. $4^{\text {th }}$ Intern. Scientific and Practical Conference "Environment. Technology. Resources". Latvia, Rezekne, 26-28 June, 2003, p. 238-243.

2. Sparnina, M., Rancane, S., Lebedeva, G., Telysheva, G. Influence of lignosilicon on productivity of winter rye in biological agriculture. In: Proc. $5^{\text {th }}$ Intern. Scientific and Practical Conference "Environment. Technology. Resources". Latvia, Rezekne, 16-18 June, 2005, p. 123 -128.

3. Lebedeva, G., Telysheva, G., Tiltina, L., Rancane, S.. Introduction of lignosilicon in soil simultaneously with seeds and its influence on productivity of buckwheat in organic farming. In: Proc. $7^{\text {th }}$ Intern. Scientific and Practical Conference "Environment. Technology. Resources", Latvia, Rezekne, 25-27 June, 2009, V. 1, p. 118-124.

4. Lebedeva, G., Telysheva, G., Rancane, S., Tiltina L. Application of lignosilicon in growing of red clover (Trifolium pratense L.). - In: Proc. $6^{\text {th }}$ Intern. Scientific and Practical Conference "Environment. Technology. Resources". Latvia, Rezekne, 20 -22 June, 2007, p. 141 -149.

5. Lebedeva, G., Telysheva, G., Tiltina, L., Volperts A. Efficacy of siliceous lignin products application for biological agriculture exemplified by experiments with red clovers. - In: Proc. $14^{\text {th }}$ Intern. Meeting of the Humic Substances Society "From Molecular Understanding to Innovative Applications of Humic Substances". Russia, Moscow - St. Petersburg, 14-19 September, 2008, V. 2, p. 673-676.

6. Voronkov, M., Zelchan, G., Lukevics, E. Silicon and Life. Biochemistry, Pharmacology and Toxicology of Silicon Compounds. Riga, Zinatne, 1978, 587 pages.

7. Matevosyan, G., Shishov, A. Application of plant growth regulators, resistance inducers, and organic fertilizer Agrovit-Kor for potato growing. Agrokhimiya, 2006, № 5, p. 56-64 (in Russian).

8. Central Statistical Bureau of Latvia. Potato Crop Average Yield. (viewed 16.02.2011.) Available: http://data.csb.gov.lv/.

9. Fruit and Vegetable Processing Products. Determination of Nitrates. GOST 29270-95 (in Russian)

10. Latvian Environment, Geology and Meteorology Centre. Meteorology. (viewed 21.02.2011.) Available: http://www.meteo.lv/public/30111.html. 